ARTICLE HISTORY: Received: September 13, 2021 Accepted: November 5, 2021 Published: November 13, 2021

\title{
ОСНОВЫ ОРГАНИЗАЦИИ И ФУНКЦИОНИРОВАНИЯ ТУРИСТИЧЕСКОЙ ОТРАСЛИ В СОВРЕМЕННОМ ПЕРИОДЕ
}

\author{
Магулаева Аминат Ариабиевна \\ Кандидат биологических наук, дочент \\ Карачаево-Черкесский государственный университет им.У.Алиева
}

Современная жизнь человека формирует среду обитания, в которой он трудится, удовлетворяет свои базовые потребности, в еде, во сне, в отношениях с противоположным полом, но ему присуще такое действие как отдых и путешествия, во время которого человек восстанавливает свой организм, набирается энергией и силой.

Трудовым законодательством предусмотрено ежегодное время отдыха, которое именуется отпуском. В конституции России за гражданами закреплено право на свободное и беспрепятственное передвижение, выезд за границу и возвращение на родину. Соответственно туризм это право на отдых, которое граждане России могут осуществлять в удобное для них время[1, стр.65].

Исторически человеку было свойственно передвигаться, целями передвижения того времени была торговля, участив в военных конфликтах, завоевание новых территорий и пространств. Как явление жизнедеятельности человека понятие туризм получает особую популярность в середине двадцатого столетия, после глобальных военных действий на территории Европы.

Туризм происходит от французского слова tourisme это прогулка, поездка, передвижение. Соответственно смена локаций и морально -психологическое состояние человека побуждает его путешествовать, видеть новые страны, посещать курорты, знакомится с культурой и обычаями народов, посещать музеи, выставки и достопримечательности, укреплять здоровье и т.д. Всемирная туристическая организация приняла рекомендации по осуществлению туристической индустрии, разработала регламенты и стандарты. Передвижение в другую среду обитания для осуществления познавательных, эстетических, деловых и торговых целей, продолжительностью менее одного года считаются туристической поездкой.

В настоящее время научное сообщество рассматривает туристическую отрасль как приоритетное направление развития экономики и социально - производственной сферы, а также оказания и предоставления услуг. Международные и отечественные эксперты туристической сферы определяют туризм как взаимосвязанную систему, в которых сосредоточены социально-экономические отношения, возникающие в местах временного пребывания, которые не связаны с производственной и трудовой необходимостью, а носят познавательный характер. Во время посещения туристических и рекреационных объектов человек поправляет здоровье, наполняется энергией, восстанавливает силы.

Сфера туризма на современном этапе приобретает два основных вектора развития государства. Так, существует: внутренний туризм, когда жители страны не выезжают за пределы границ своего государства, а путешествуют внутри, посещая туристско-рекреационные зоны и внутренние курорты. Государства заинтересованы в развитии внутреннего туризма, так как поток финансовых средств, которые тратят отдыхающие, оседает внутри страны. Практика реализации внутреннего туризма показывает, что в мировом масштабе люди путешествуют процентов 70-80 внутри своего государства. [2.c.35]

Существует второй вид туризма, такой как международный. Его можно охарактеризовать как путешествие за пределы границ государства постоянного проживания.[3, с. 79] Эксперты мирового туристической сферы выделяют 3 основные направления выезда граждан для отдыха и туризма, это страны Европейского союза, на их долю приходиться более 60 процентов, 11 около 30 процентов приходиться на страны центральной и южной Америки, оставшиеся 10 процентов на все остальные направления. Европа привлекает международного туриста множеством факторов:

Во-первых, удобное расположение. Все страны туристического кольца Европы находятся на достаточно близких расстояниях.

Во-вторых, упрощенное передвижение внутри Европейского союза так как, оформив визу в одну из стран, человек имеет право посетить еще и соседние государства, так как на территории Европы действует Шенгенское соглашение.

В-третьих, богатое историческое и культурное наследие. Жители планеты считают познавательным посещение стран Европейского союза. В-четвертых, разнообразие туристско-рекреационных зон, от побережья Атлантического океана и Средиземного моря до горнолыжных и всесезонных курортов Альп, а также любителям шопинга есть, где удовлетворить свои потребности.

Таким образом, на современном этапе происходит синтез внутреннего и международного туризма присущий для Европейского континента. 
Эксперты туристической индустрии разделяют карту туристических зон государств, на активную и пассивную форму. Так, активной формой для государств предоставляющих туристические услуги считаются частые перемещения, приезд иностранцев или жителей своего государства, траты финансовых ресурсов, бронирование отелей и гостиниц, пополнение бюджетов. Пассивная форма это передвижения наших граждан в другие страны, вывоз финансовых средств, трата их на чужой территории и пополнение бюджетов других туристических зон.

Современный туризм подразделяется по нескольким основания, в зависимости от различных условий, таким как цели отдыха, продолжительности путешествия, способа передвижения, времени и места путешествия, сезона и т.д. [4]

Таким образом, экспертное и научное сообщество в зависимости от цели поездки выделяют следующие виды:

- Рекреационно-восстановительный и оздоровительный туризм. Может быть охарактеризован как туризм для здоровья, посещение курортов находящихся на побережье моря, бальнеологических территорий, санаториев с грязелечением и наличием минеральных источников и т.д.

- Культурно-познавательный туризм. Может характеризоваться расширением интеллектуального и мировоззренческого развития человека, это посещение туристических зон культурно-исторического наследия, музее под открытым небом, памятники истории и археологии и т.д.

- Научно-исследовательский и экспедиционный туризм. Характеризуется проведением научных экспедиций, научных исследований во время путешествия. А также в настоящее время набирает обороты образовательный сегмент данного вида туризма, когда представители молодого поколения выезжают за пределы мест проживания в целях отдохнуть и получить новые знания.

- Деловой или бизнес-туризм. Может характеризоваться как передвижение бизнес элиты по деловым и коммерческим целям, переговоры, отдых, деловые встречи, завтраки, обеды, ужины с инвесторами и новыми компаньонами яркое отражение данного вида туризма.

- Спортивный туризм, характеризуется активными спортивными занятиями во время путешествия, походы в горы, погружение под воду и т.д. • Экстремально-приключенческий туризм. Данный вид туризма становится весьма популярным у отдыхающих, особенно представителей молодого поколения желающих, испытать острые эмоции, серфинг, спуск на байдарках по горным рекам, прыжки с высотных зданий, все эти экстремальные развлечения во время активного отдыха.

- Экзотический или экотуризм, данный вид характеризуется желанием отдыхающих попробовать пожить, поесть, почувствовать вест колорит культуры, быта и жизни того народа на территории которого находится на отдыхе. В современных условиях набирает популярность.

- Религиозно-паломнический туризм, данный вид туризма присущ религиозным группам населения, которые во время отдыха посещают святые места, храмовые комплексы, религиозные достопримечательности.

Подразделяя туристическую отрасль по способам передвижения, туризм может быть:

- Пешеходный, когда отдыхающие путешествуют, пешком передвигаясь на ногах;

- Автомобильный или автотуризм, железнодорожный, авиационный, водный, мотоциклетный, велосипедный, конный, смешанный. Разновидностью туристической отрасли по движению туристических потоков выделяют: • Постоянный и беспрерывный;

- Сезонный, в зависимости от времени года, погоды, природноклиматических условий.

Разновидностью туризма по организационным основаниям различают:

- Индивидуально организованный туризм,

- Г рупповой или коллективный туризм,

- Самостоятельный или туризм неорганизованный.

C развитием информационно-телекоммуникационных технологий стали популярными новые разновидности туристических услуг, так выделяют информационно-виртуальной, космический, цифровой туризм.

Современная жизнь диктует трансформацию предоставления туристических услуг, появлению новых направлений и векторов развития.

На туристических картах появляются новые маршруты и новые курорты, готовые удивить даже самых искушенных туристов. Но развитие туризма должно осуществляться с учетом разновидности факторов, которые влияют на уровень и качество сервиса, на туристический поток и формирование ценовой политики.

С экономической точки зрения должны учитываться обстоятельства уровня доходов и качества жизни, только обеспеченный всеми важными потребностями для жизни человек, будет думать об отдыхе и путешествиях.

Важным обстоятельством на современном этапе стала санитарноэпидемиологическая обстановка. Распространение новой коронавирусной инфекции подвергло туристическую индустрию к серьезным изменениям и колебаниям. На протяжении 2020 года существенно был сокращен туристический поток по всем 
без исключения направлениям, так как многие страны мирового сообщества закрыли свои границы для посещения.

Важным фактором является географическое положения курортной зоны, так как теплый климат, привлекает большое количество туристов, которые проживают в северных широтах, наличие уникальных характеристик, рельеф, транспортная доступность, наличие авиационного и железнодорожного сообщения, качественных дорог и соответствующей транспортной инфраструктуры является важной составляющей для приезда отдыхающих.

Привлечение туристов зависит от стабильности политической и финансовой системы, а также обеспечения мер безопасности для отдыхающих. Уровень взаимоотношений государств на дипломатической арене, подписанные договоры и соглашений в сфере экономического сотрудничества, способствуют увеличению туристического потока между странами.

Важным фактором привлечения туристов является наличие на территории курорта или рекреационной зоны культурно-исторических памятников и формирование вокруг них всей туристической инфраструктуры.

Рассматривая факторы, которые влияют на туристический поток необходимо отметить огромную роль государства, при организации туристической политики и создании условий для ее осуществления, мер и форм стимулирования туристической индустрии. В этой связи, считаю необходимым подробно осветить вопросы организации деятельности государственной властной системы в сфере туризма и формах поддержки.

На современном этапе индустрия в сфере туризма представляет собой развитую сеть гостиничного фонда, санаторно-рекреационных зон для прохождения процедур лечения и оздоровления, мест общественного питания, развлекательных и досуговых учреждений, где отдыхающие получают весь спектр услуг.

К туристической индустрии относятся организации туристических операторов и специализированных агентств, инструкторов, гидов, экскурсоводов, проводников, экспедиторов и других сотрудников, которые отвечают за познавательную, развлекательную, деловую составляющую при организации туристической деятельности.

Таким образом, сфера предоставления туристических услуг представляет собой масштабную деятельность в которой принимает участие огромное количество обслуживающего персонала, дающая множество рабочих мест, формирующая определенный кластер социальноэкономических и трудовых отношений

1 Бугорский, В. П. Организация туристской индустрии. Правовые основы [Текст]: учеб. пособие для СПО / В. П. Бугорский. - М. : Издательство Юрайт, 2019. - 165 с.

2. Золотовский, В.А. Правовое регулирование туристской деятельности [Текст] : учебник / В. А. Золотовский, Н.Я. Золотовская - М. : Издательство Юрайт, $2019-247$ с.

3. Каменец, А. В. Молодежный социальный туризм [Текст] : учеб.пособие для академического бакалавриата / А. В. Каменец, М. С. Кирова, И.А. Урмина ; под общ. ред. А. В. Каменца. - 2-е изд., испр. и доп. - М. :Издательство Юрайт, 2019 - 192 с.

4. Чудновский, А.Д., Жукова, М.А. Управление индустрией туризма России в современных условиях [Текст]: учебное пособие. Чудновский, М.А. Жукова / - М.: КНОРУС, 2010.- 416с. 